
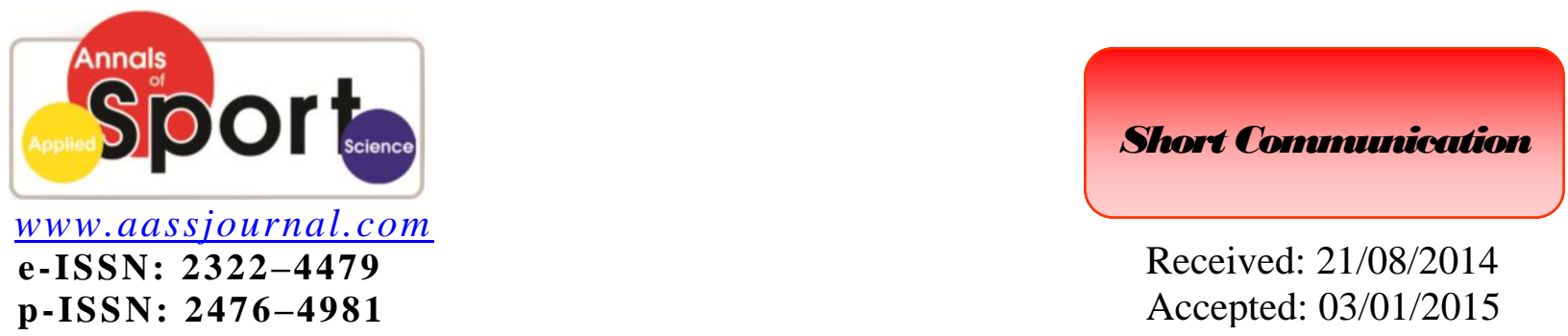

Received: $21 / 08 / 2014$

Accepted: 03/01/2015

\title{
Comparison of Alexithymia in Athlete and Non-Athlete Students
}

\section{${ }^{1}$ Heidar Jodat ${ }^{*},{ }^{2}$ Abdollah Ghasempour, ${ }^{2}$ Abotaleb Tavakoli}

1. Education Office, Miandoab, West Azarbaijan, Iran.

2. Department of General psychology, Faculty of Education and Psychology, University of Mohaghegh Ardabili, Ardabil, Iran.

\begin{abstract}
Today, researchers consider sports as one of the methods of reinforcement in the development of psychological parameters. The aim of the present study was to compare the alexithymia and its components, in athletes and non-athletic adolescents. Its components consist of difficulty in identifying feelings (DIF), difficulty in describing feelings (DDF), and externally oriented thinking (EOT). The statistical sample of the research included 100 athlete students and 100 nonathlete students, who were selected using multistage cluster sampling. They were asked to fill out the Farsi version of the Toronto Alexithymia Scale-20. The obtained results showed that there were significant differences in the mean scores of the alexithymia and its three components: difficulty in identifying feelings, difficulty in describing and externally oriented thinking in both groups $(\mathrm{P}=0.001, \mathrm{P}=0.001, \mathrm{P}=0.001$ and $\mathrm{P}=0.008$, respectively). The results revealed that athletic students had less emotional problems than non-athlete students; it is recommended that physical activity be part of the strategies to improve emotional health among non-athletic students.
\end{abstract}

Key Words: Athlete, Non-Athlete, Alexithymia, Students.

Corresponding Author:

Heidar Jodat

E-mail: h_jodat@yahoo.com 


\section{INTRODUCTION}

Nowadays, poverty of movement induced industrial life has created many problems for humans; therefore, exercise is one of the essential needs of the modern person. Psychologists and exercise specialists have consistently affirmed the vital role of exercise and physical fitness on the development of mental skills such as happiness (1) and reduction of psychological problems, emotion, and affection; including depression (2).

One of the psychological and emotional problems that has attracted the attention of psychologists and experts in the health field is alexithymia. Alexithymia refers to deficit in the ability to recognize and express emotions, use of concrete speech and thoughts related to external events, and a paucity of fantasy life. It has three core features. (a) Difficulty identifying feelings, which refers to "a limited identification of a person's own mood states and failure to identify emotions". (b) Difficulty describing feelings, which refers to "a limited ability to recognize one's own emotions and verbalize them". (c) Externally-oriented thinking, which refers to "a cognitive style that shows a preference for external detail of everyday life rather than thought content related feelings, fantasies and other aspects of a person's inner experiences" (3).

Emotions are not only an intrinsic part of competitive sport; they are widely believed to influence performance in sport. Consequently, the ability to regulate emotions successfully is regarded by many as an important psychological skill in athletes. Although most humans are able to recognize, and report the experience of a variety of emotions, because emotion is a term derived from everyday language, identifying the necessary and sufficient conditions for something to qualify as an emotion has been plagued with difficulty (4).
Various researchers demonstrated in their research that exercise, physical activity and movement have an important role in reducing the emotional and psychological problems. Mostafai (2012) found that level of negative emotions, such as depression and anxiety in female athletes, is significantly lower than non-athletic women (1).

Behroozi and Abdimoghadam (2014) concluded in a study that athletic conscripts had less psychological, effective and emotional disorders than non-athletic conscripts (5). Ghasempour et al. (2013) showed that physical activities are associated with increased levels of happiness and psychological well-being (6). Stanger et al. (2012) demonstrated that people who do not exercise have more blunted emotions compared to their athletic counterparts (7). Carless and Douglas (2010) found that physical exercise has a positive effect on the mental health of participants and decreases anxiety and depression in them (8). Strohle (1996) showed that exercise and physical activity can reduce depression and anxiety (9). In Cabrera and Padilla's research (2004), it was shown that student athletes have relatively high emotional intelligence, which has a positive impact on their athletic performance (10). Cox (2002) stated that athletes have lower negative emotional states and higher vitality in comparison with nonathletes (11). Ghasempour et al. (2014) revealed that athletic students were in better positions with regard to psychological wellbeing, positive relationships with others and purpose in life than non-athletic students (12).

Overall, based on what was said, it can be concluded that exercise, physical activity and movement are among the factors that play important roles in reducing mental and emotional disorders. Although research evidence indicates the role of exercise in improving psychological and emotional problems is essential, so far no research has 
examined the role of sport, physical activity and movement in reducing emotional disorders in adolescents. Furthermore, no studies consider the importance of exercise in reduction of alexithymia and its components in adolescent students. So by reviewing how these variables can play an effective role in student athletes and nonathletes by comparing psychological factors, possible differences can be realized between the negative emotional structures of the two groups. If there is a significant difference, it should be possible to specifically identify the desired features and emphasize them as well as it being possible to improve the condition of Sport Science and Physical Education in adolescent students. So, the question is: is there significant difference between athletic and non-athletic students with regard to alexithymia and its dimensions?

\section{MATERIALS AND METHODS}

Due to the subject of this study and the nature of its variables, the type of this study was post event (causal comparative), in which researchers tried to evaluate, compare, and explain the obtained results (13).

Participants. The population consists of all the high school male students of ordinary schools of Miandoab in the academic year 2012-2013, which came to approximately 6,000 people. Sample size was calculated using the Cochran formula, taking into account the measurement error, equal to 0.08 , and confidence interval of 0.95 (14), equalling 146 people.

Finally, in view of the likelihood of dropped subjects and high external validity, 200 people were selected as the sample, including 100 student athletes (mean age; 15.55 and SD; 0.91) and 100 non-athlete students (mean age; 15.85 and SD; 0.83). Randomized multistage cluster sampling was used. For the sampling, first, Miandoab City was divided into five geographical areas and from these regions, two regions were selected randomly as the first stage clusters. In the next step, in the aforementioned two regions, high school boys from two high schools, and from each high school, a few classes were selected as clusters. In the third stage, the desired sample was selected randomly from each class.

Inclusion criteria of the student athletes in this research were: the selected have been members of sports clubs for at a minimum of one year continuously (up until the selection), and in every week, two sessions of regular exercise have been carried out. Furthermore, they must be in the age range of 14-16 years. Exclusion criteria were severe physical illness, a history of hospitalization in psychiatric centers, or referral to a psychiatrist due to mental disorders that resulted in limited sport and physical activity.

Inclusion criteria of non-athletes were that during the previous year, with the exception of sports in school, the subjects have not had physical activity and were in the age range of 16-14 years. The exclusion criteria also include those with a history of hospitalization in psychiatric centers, or visits to a psychiatrist because of mental disorders.

Tools. The FTAS-20 is a Farsi version of The Toronto Alexithymia Scale [TAS-20; (15)] validated for the Iranian population (16). The FTAS measures three components of alexithymia including difficulty in identifying feelings (DIF), difficulty in describing feelings (DDF), and externally oriented thinking (EOT) on a five-point Likert scale, which ranged from 1 (strongly disagree) to 5 (strongly agree). The TAS-20 has demonstrated good psychometric properties (15-17). Adequate psychometric properties of the scale have been reported for the Iranian population (16).

Cronbach's (alpha) coefficients of the FTAS-20 were $0.85,0.82,0.75$, and 0.72 for the overall alexithymia score and subscales 
of difficulty in identifying feelings, difficulty describing feelings, and externally oriented thinking, respectively.

Test-retest reliability, in a sample of 67 participants, was calculated on two occasions over a four week period. Correlation coefficients ranged from 0.80 to 0.87 for the overall and subscales' scores. All correlation coefficients were significant at $p=0.001$ (15). The reliability of this test in this study was 0.61 using Cronbach's (alpha).

Procedure. Athlete and non-athlete students completed the Farsi version of the Toronto Alexithymia Scale-20 in the classroom without the teacher present (10-15 min) following an explanation of the advantages of this research. In order to comply with research ethics and to attract the cooperation of the subjects, they were initially apprised on the general objectives of the study and then they were asked to answer the questions whilst remaining anonymous. It is necessary to note that people who participated in this project were enthusiastic to take part and the subjects were assured that their information would be kept confidential and the results would be issued in a group and statistically rather than individually.

Statistical Analysis. For data analysis descriptive statistics (Mean \pm SD) and analysis of variance, MANOVA was used and $\mathrm{p}<0.05$ was considered to be significant. Statistical analysis was performed using SPSS-16.

\section{RESULTS}

Table 1 shows the mean and standard deviation of the research variables for the two groups. Obtained values of Kolmogorov-Smirnov for all variables were not significant between the two groups. These values indicate that the scores of the examined scales have no problem in terms of normality in the samples and data. Conversion methods will not be used to adjust them and the analysis of the scales will not disturb the results. Furthermore, all variables are normally distributed according to the Kolmogorov-Smirnov values. Thus, MANOVA test can be used to analyze the findings of this study.

Table 1. Descriptive characteristics for alexithymia and its components in two groups

\begin{tabular}{ccccc}
\hline Variable & group & Mean \pm SD & Kolmogorov-Smirnov & sig \\
\hline \multirow{2}{*}{ DIF $^{*}$} & Athletic & $18.88 \pm 5.31$ & 0.61 & 0.84 \\
& Non-athletic & $25.31 \pm 5.48$ & 0.79 & 0.55 \\
\hline \multirow{2}{*}{ DDF $^{* *}$} & Athletic & $13.57 \pm 3.75$ & 0.91 & 0.36 \\
& Non-athletic & $17.98 \pm 6.10$ & 0.83 & 0.46 \\
\hline \multirow{2}{*}{ EOT $^{* * *}$} & Athletic & $22.19 \pm 3.63$ & 0.72 & 0.67 \\
& Non-athletic & $23.39 \pm 2.56$ & 0.80 & 0.58 \\
\hline \multirow{2}{*}{ Alexithymia (total score) } & Athletic & $54.64 \pm 9.50$ & 0.98 & 0.29 \\
& Non-athletic & $66.68 \pm 9.51$ & 1.13 & 0.10 \\
\hline${ }^{*}$ DIF: $:$ Difficulty in Identifying Feelings, ${ }^{* *}$ DDF: Difficulty & in & Describing & Feelings, \\
${ }^{* * *}$ EOT: Externally Oriented Thinking & & & &
\end{tabular}

Before using the test of analysis of variance, the assumption of homogeneity of variance was studied using the Levene test. According to the results of the Levene test, the assumptions of homogeneity of variances of the research variables were verified in the two groups. This test was not significant for any of the variables.

As can be seen in Table 2, the results of the research demonstrated that there is a significant difference between the DIF in the athlete and non-athlete students $(\mathrm{P}=0.001)$. 
The athlete students therefore are better at identifying feelings than the non-athlete students. A comparison of the average of the DDF in athlete and non-athlete students also showed a notable difference $(P=0.001)$. The athletic students had lower DDF scores in comparison with the non-athletic students. A comparison of the average of the DOF indicated that athlete students have less DOF than non-athlete students and the difference was significant $(\mathrm{P}=0.008)$. With consideration to alexithymia, the results show that fewer athlete students had alexithymia in comparison to the non-athlete students $(\mathrm{P}=0.001)$.

Table 2. MANOVA for alexithymia and its components

\begin{tabular}{cccc}
\hline Variable & Mean Square & F & $\boldsymbol{p}$-Value \\
\hline DIF $^{*}$ & 2067.24 & 79.79 & 0.001 \\
DDF $^{* *}$ & 972.40 & 37.89 & 0.001 \\
EOT $^{* * *}$ & 72 & 7.25 & 0.008 \\
Alexithymia (total score) & 7248.08 & 80.14 & 0.001 \\
\hline${ }^{*}$ DIF: Difficulty in Identifying Feelings, ${ }^{* *}$ DDF: & Difficulty in & Describing \\
Feelings, ${ }^{* * *}$ EOT: Externally Oriented Thinking & &
\end{tabular}

\section{DISCUSSION AND CONCLUSION}

The aim of the present study was to compare alexithymia and its components; DIF, DDF and EOT in athletes and nonathletic adolescents. The results showed that generally, the average scores of athletic students are less than the average scores of non-athletic students in the variables of DDF, DIF, EOT and alexithymia. These differences were significant and presented the better emotional conditions and better health in athlete students over the nonathlete students.

On basis of these results, our first hypothesis was supported. The results are consistent with results of Mostafai and Ghasempour et al. (1, 12). Mostafai (2012) showed that disorders and problems (mental, emotional and affective) are less frequent in athletes than in non-athletic people (1). Ghasempour et al. (2014) indicated that exercise and physical activity leads to increased psychological well-being (12). In explaining the results of this study, it can be said that student athletes in different sports not only acquire the physical growth, they also experience growth in their mental, emotional, and personality dimensions.
Exercise and physical activity are effective and important in expressing and regulating emotions, creativity, curiosity, personal self-control, a sense of hope, increased self-esteem, psychological wellbeing and happiness $(1,6,10,12)$.

Exercise and physical activity are associated with increased positive aspects that are conditioned to respond and provide opportunities to reduce the negative impacts of threatening situations and antigenics (10). By creating an appropriate context to increase their sense of empowerment and self-worth (11), athletic people are able to reduce psychological, emotional and affective (e.g., alexithymia and its components) problems more so than nonathletic people. Regular exercise and physical activity can improve positive attitude and change negative beliefs and dysfunctional views on the life of people and their surrounding environments. These changes, in turn, reduce emotional disorders (including deficits in emotional selfregulation, the inability to recognize and verbal descriptions of personal emotions) in athletes compared to non-athletes.

Moreover, it is likely that student athletes use sport and physical activity as a method 
and of coping with the worries and stresses that are caused by the repetitive nature of life. This, in turn reduces and controls psychological and emotional problems such as alexithymia.

In explaining these results, it is assumed that individuals have different skills in their use of positive emotions and processing emotional balance constructively and efficiently. These skills can be caused by factors such as participation in physical activity and sport. Participation in sport and physical activities are effective and safe ways to reduce emotional stress and negative emotions (e.g. sadness and anxiety), increase social and interpersonal skills and employ productive and efficient strategies for regulating emotions in stressful situations (1, 7). In terms of psychological, physical and sporting activities, exercise provides opportunities to divert the attention of the person from stressful conditions and create a context for improving body image, positive attitude towards oneself, communicating with others, positive emotions and mental health, emotionally and physically $(6,11)$. This probably reduces the rate of alexithymia and its components (Externally Oriented Thinking, Difficulty in Describing Feelings and Difficulty in Identifying Feelings) in student-athletes.

Overall, the results showed that the situations of athletic adolescents, compared to non-athletic adolescents, in terms of alexithymia and its components, were better. According to the findings, encouraging students to participate in physical activity and exercise in their teenage years can reduce their psychological problems, help to control these problems, and help to improve mental health. It is therefore necessary for officials, and those involved in educating and training students in youth sports, be more sensitive and carry out short-term and long-term planning in this context in order to provide necessary facilities for this stratum of society.

It is suggested that future research is carried out on students from other educational levels, such as junior and female students. It is necessary to repeat this study in schools in other cities to discover whether or not the results obtained in this study are true for other situations. It is suggested that relevant authorities are applied to in order to attempt to reduce and control mental and emotional problems, such as alexithymia and its components, in students. This can be done by giving more attention to sport and physical activity and in research and planning relating to the control and reduction of psychological problems.

Finally, it is necessary to note the limitations of this study in the interpretation of its results. Firstly, the appraisal of alexithymia was based on the self-report of subjects, which may be biased. Another limitation related to the sample group, which takes caution in generalizing the results to the external subjects.

\section{APPLICABLE REMARKS}

- Physical activity can be part of the strategies to improve emotional health among non-athletic students.

\section{REFFRENCES}

1. Mostafai A. The comparison between athlete women and non athlete women regarding to mental health and happiness. Annals of Biological research. 2012;3(5):2144-7.

2. Pittet I, Berchtold A, Akre C, Michaud PA, Suris JC. Sports practice among adolescents with chronic health conditions. Archives of pediatrics \& adolescent medicine. 2009;163(6):565-71.

3. Modestin J, Furrer R, Malti T. Study on alexithymia in adult non-patients. Journal of psychosomatic research. 2004;56(6):707-9. 
4. Uphill MA, Lane AM, Jones MV. Emotion Regulation Questionnaire for use with athletes. Psychology of Sport and Exercise. 2012;13(6):761-70.

5. Behroozi A, Abdimoghadam S. Role of sports on scales of mental health among a battalion of Iranian conscripts. annals of military and health sciences research. 2014;12(1):29-33.

6. Ghasempour A, Jodat H, Soleimani M, Zhalehshabanlo K. Happiness as a Predictor of Psychological Well-Being of Male Athlete Students. Annals of Applied Sport Science. 2013;1(2):25-32.

7. Stanger N, Kavussanu M, Willoughby A, Ring C. Psychophysiological responses to sport-specific affective pictures: A study of morality and emotion in athletes. Psychology of Sport and Exercise. 2012;13(6):840-8.

8. Carless D, Douglas K. Sport and Physical Activity for Mental Health: Blackwell Publishing Ltd; 2010.

9. Strohle A. Physical activity, exercise, depression and anxiety disorders. Journal of neural transmission (Vienna, Austria : 1996). 2009;116(6):777-84.

10. Cabrera NL, Padilla AM. Entering and Succeeding in the "Culture of College": The Story of Two Mexican Heritage Students. Hispanic Journal of Behavioral Sciences. 2004;26(2):152-70.

11.Cox RH. Sport Psychology: Concepts and Applications. 5th ed: McGraw-Hill; 2002.

12. Ghasempour A, Jodat H, Soleimani M. A comparison of Psychological Well-Being in Athlete and Non-Athlete Students. Journal of Rafsanjan University of Medical Sciences. 2014;13(2):193-204 [Article in Farsi].

13.Delavar A. Reasearch method in psychology and educational science. 4th ed. Tehran: Roshd Pub; 2006 [Book in Farsi].

14.Baryaji M, R. M. Relationship between Leadership- Followership Styles and Fear of Meta-cognition Assessments. Journal of Industrial/Organization Psychology. 2012;3(12):87-97 [Article in Farsi].

15.Bagby RM, Parker JD, Taylor GJ. The twenty-item Toronto Alexithymia Scale--I. Item selection and cross-validation of the factor structure. Journal of psychosomatic research. 1994;38(1):23-32.

16. Besharat MA. Reliability and factorial validity of a Farsi version of the 20-item Toronto Alexithymia Scale with a sample of Iranian students. Psychological reports. 2007;101(1):209-20.

17. Thorberg FA, Young RM, Sullivan KA, Lyvers M, Connor JP, Feeney GF. Alexithymia, craving and attachment in a heavy drinking population. Addictive behaviors. 2011;36(4):427-30. 


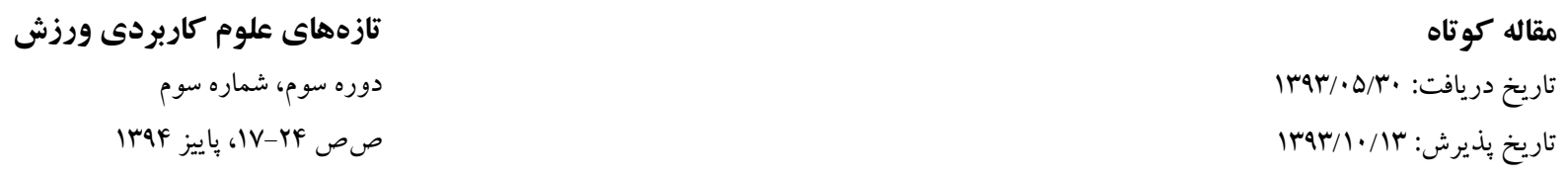

\title{
بررسى آلكسى تايميا در دانشآموزان ورزشكار و غيرورزشكار 'حيدر جودت*، ‘عبداله قاسميور، 'ابوطالب توكلى
}

\author{
I. كارشناس ارشد تربيتبدنى، آموزش و يرورش شهرستان مياندوآب، مياندوآب، ايران. \\ r. كارشناس ارشد روانشناسى عمومى، دانشگاه محقق اردبيلى، اردبيل، ايران.
}

جكيده

امروزه محققان ورزش را به عنوان يكى از روشهاى تقويتكننده در رشد مؤلفهاى روانشناختى در نظر مى يَيرند. هدف از يزوهش حاضر

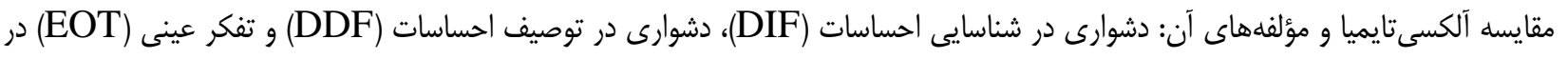

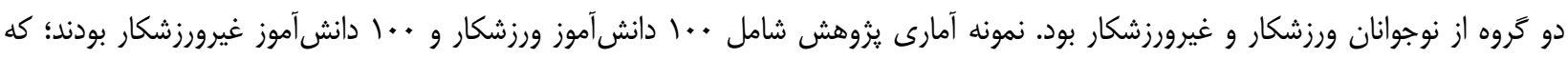

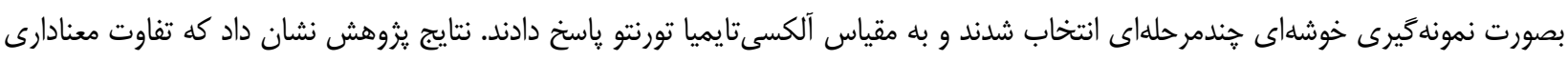

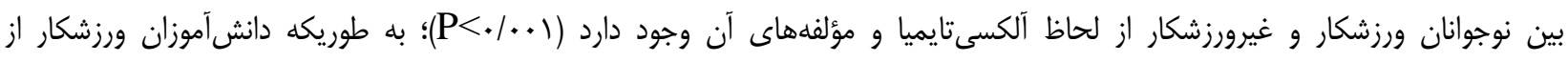

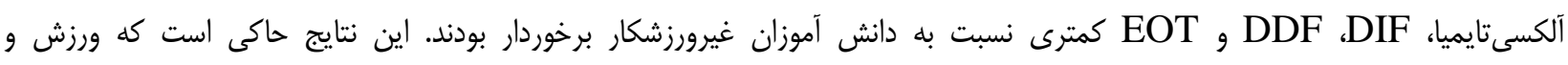
فعاليتهاى بدنى عاملى تأثيركذار در كاهش مشكلات هيجانى در نوجوانان مىباشند. وازَّان كليدى: ورزشكار، غيروززشار، آلكسىتايميا، دانشآموز.

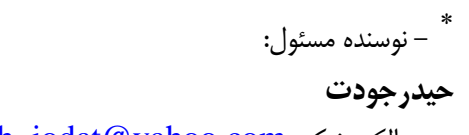

بست الكترونيك: بودن hajodat@yahoo.com 